\title{
The Fermentation of Parchment Ohmic Technology Used to Process Coffee Beans (A Wet Black Coffee) Aroma
}

\author{
Reta ${ }^{1}$, Henny Poerwanty $\mathrm{AS}^{1}$, Salengke ${ }^{2}$, Syamsia $^{3}$, Arnida $\mathrm{M}^{1}$ \\ *1 Department of Agroindustry, Pangkep State Polytechnic of Agriculture, Pangkep, South Sulawesi, Indonesia \\ ${ }^{2}$ Departmen of Food Science and Technology, Hasanuddin University,Jl. Perintis kemerdekaan Km.10 \\ Makassar, South Sulawesi, Indonesia \\ ${ }^{3}$ Department of Agrotecnology, University Universitas Muhammadiya Makassar, Makassar, South Sulawesi, \\ Indonesia
}

\begin{abstract}
This study aimed (1) to determine the effect of temperature on and (2) to determine the fermentation time and the effect of bromelin enzyme of coffee beans aroma on). The process of fermentation of coffee beans using the ohmic technology with the addition of pineapple extract. The treatment used in the fermentation with Ohmic technology was the temperatures of $35^{\circ} \mathrm{C}$ dan $45^{\circ} \mathrm{C}$; and fermentation times were 6, 12, and 18 hours. The observation parameters included $\mathrm{pH}$, caffeine content, and organoleptics. The research results indicated that in the fermentation of the coffee beans using Ohmic technology at the temperature of $35^{\circ} \mathrm{C}$ and the time fermentation of 12 hours, the caffeine content (1.6\%) became $0.047 \%$, and the temperature of $35^{\circ} \mathrm{C}$ and the time of fermentation was 12 hours had produced $\mathrm{pH}$ of 4.81 , and the temperature of $45^{\circ} \mathrm{C}$ with the time fermentation of 6 hours, high caffeine value of $0.147 \%$, and at $45^{\circ} \mathrm{C}$ with the time fermentation of 18 hours had produces $\mathrm{pH}$ value of 5.83. The organoleptic description of the flavor attributed with temperature of $35^{\circ} \mathrm{C}$, the temperature flavor attributed and the time fermentation of 12 hours, the average body score was 4.94 , while the bitterness was 3.7 , and at the temperature of $45^{\circ} \mathrm{C}$ and the time fermentation of 12 hours produced the body weight scores of 3.49 , while the bitterness of 3.45 . The fermented coffee beans with the clinical technology was very effective to use in.ohmci technology because it could provide a relatively uniform and evenly distributed heating system.
\end{abstract}

Keywords : Fermentation, Technology ohmic, Coffee.

\section{INTRODUCTION}

Coffee is a plantation plant that has a high economic value. Coffee not only serves as a source of foreign exchange but also a source of income for more than one and a half million coffee farmers in Indonesia [Raharjo, et al., 2012]. Indonesia's position is considered strategic enough in the international coffee sector, as Indonesia is the third largest coffee exporting country after Brazil and Vietnam [FAO., 2012]. The productivity of Indonesian coffee from 1980-2017 amounted to 637,539 tons per year. If in 1980 the export volume of Indonesian coffee amounted to 238,677 tons with export value of US \$ 656 million, then in 2015 the export volume will increase to 502.021 tons or US \$ 1,198 million [ICO., 2012., 2015] [Dirjend Perkebunan., 2016]. 
Coffee is processed by several ways of processing that is wet and dry way. One of the stages of wet processing of arabica coffee that determines the quality is fermentation. Fermentation aims to remove the

remaining layer of mucus on the skin surface of the coffee bean horn after the stripping process. However, the process of fermentation is too long will produce rice coffee that smells fragrant because of the breaking of the component content of the institution [Ciptadi., 1985].

Controlled fermentation by fermenters is performed to control the temperature during the fermentation process. This fermentation technology can be combined with the addition of microorganisms / enzymes or without microorganisms [Yusianto, et al., 2013]. According to Yusianto et al (2013), this study uses a double jacketed tank as a fermentor. Fluid heating is done by using an electric heater. The temperature of the heating fluid is so fluctuating that the temperature of the coffee beans in the fermentor also fluctuates. In this study, the fermentation of coffee beans was done by using ohmic heating. This technology generates heat internally so that the heating process takes place precisely and uniformly, and easily controlled accurately [Salengke, 2002] [Ruan, et al 2001].

The fermentation process conducted in the study using the addition of bromelin enzyme derived from Pineapple (Ananas comosus L. Merr). This enzyme is

able to accelerate the process of release of mucus and solve protein and gel compounds and can lower coffee caffeine levels to be lower [Oktadine, et al., 2013].

Referring to the above description it is necessary to conduct research on the fermentation process using ohmic technology and the addition of bromelin enzymes. Treatment parameters that need to be studied include duration and fermentation temperature and its effect on coffee.

\section{METHODS AND MATERIAL}

The tool used in this research is ohmic reactor, $\mathrm{pH}$ meter orion 2 star model Milwauke (MW) 101; USA, grain moisture meter, thermometer, aluminum foil container, digital camera, measuring cup, ruler, blender, erlemenyer, bucket, basin, refrigerant, pumpkin, gunny sack, analytical balance 0.001, separator funnel, BR22 Probot type Roaring tool. Grinder type Litina, cuptest bowl, water jug, and cuptest spoon.

The materials used are arabica coffee beans originating from Enrekang Regency with altitude $1500 \mathrm{mdpl}$, pineapple fruit, water, $\mathrm{MgO}, \mathrm{H} 2 \mathrm{SO}$, Khloroform, $\mathrm{HCl} 0.0001 \mathrm{~N}$ solution as electrical conductor on ohmic.

The main activity in this research is to ferment the coffee beans on ohmic technology with the addition of pineapple extract with two factors of observation, fermentation length $(6,12,18$ hours $)$ and temperature $\left(35^{\circ} \mathrm{C}\right.$ and $\left.45^{\circ} \mathrm{C}\right)$. The second stage of the study was designed in a factorial experiment using a complete randomized design with three repetitions.

The organoleptic test with the QDA method is a method based on panelist preferences on the sample presented by involving seven panelists. Test with this method is usually used to measure the level of consumer acceptance of the products offered. Type of testing performed in this organoleptic test is the preferred method of taste and aroma with a score of 0-7 [Soekarto., et al, 1993]. 
This study was designed in a factorial experiment using a complete randomized design with three repetitions using the method of variance analysis using Statistic Package for Social Sciences (SPSS). If the results of the analysis of variance show a significant effect $(\alpha=0.05)$ then a real difference test is done using Duncan's multiple-range differential test.

An analysis of variance (ANOVA) was applied to determine the main effects of the independently studied factor (percentage of aroma and taste) on sensory attributes as assessed by panelists during the QDA procedure.

\section{RESULTS AND DISCUSSION}

Organoleptic test is conducted with the aim to know the level of taste panelis favorite level of the resulting product. Panelists are asked to give a score of 0-7 based on the preferred level.

Table 1 shows that the best cuptaste yields at $35^{\circ} \mathrm{C}$ and 6 hour fermentation time received the highest burnt value $(6,27)$ and caramel and fruity attributes at $35^{\circ} \mathrm{C}$ and fermentation time for 12 hours (5.85) and (5.83). While fermentation at $45^{\circ} \mathrm{C}$ and 6-12 hours of temperature get the lowest value on Caramel attribute (2.85) and Fruity (2.50).

\section{A. Sensory Test Aroma and Profile Based on Time and Temperature of Fermentation by Ohmic Technology}

Table 1 shows that the best cuptaste yields at $35^{\circ} \mathrm{C}$ and 6 hour fermentation time received the highest burnt value $(6,27)$ and caramel and fruity attributes at $35^{\circ} \mathrm{C}$ and fermentation time for 12 hours (5.85) and (5.83). While fermentation at $45^{\circ} \mathrm{C}$ and 6-12 hours of temperature get the lowest value on Caramel attribute (2.85) and Fruity (2.50).
Table 1. The result of sensory taste test based on temperature and time on fermentation of coffee beans

\begin{tabular}{ccccc}
\hline \multicolumn{2}{c}{ Treatment } & \multicolumn{3}{c}{ Attribute } \\
\hline $\begin{array}{c}\text { Temperature } \\
{ }^{\circ} \mathrm{C}\end{array}$ & $\begin{array}{c}\text { Time } \\
\text { (hour) }\end{array}$ & Chocolate & Caramel & Fruity \\
\hline \multirow{3}{*}{35} & 6 & 3.16 & 3.99 & 2.89 \\
& 12 & 4.87 & 5.85 & 5.83 \\
& 18 & 3.44 & 3.71 & 3.16 \\
45 & 6 & 4.04 & 3.31 & 2.50 \\
& 12 & 4.63 & 2.85 & 2.94 \\
& 18 & 3.80 & 3.34 & 4.34 \\
\hline
\end{tabular}

Figure 1 Shows on the fermentation treatment with temperature $35^{\circ} \mathrm{C}$ and long 6 hours has high burnt value. Furthermore, in fermentation with temperature $35^{\circ} \mathrm{C}$ and 12 hours have the aroma of fruity, caramel, and chocolate.

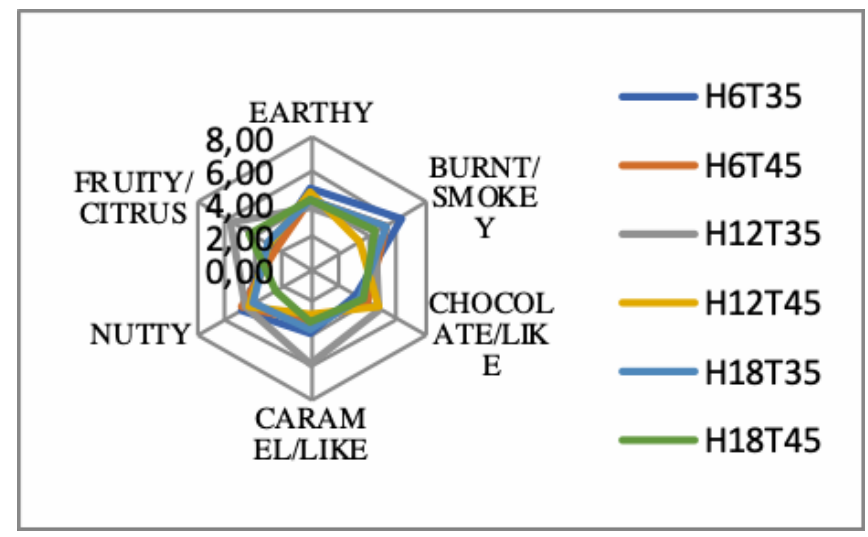

Figure 1. Profile of coffee fermentation aroma with temperature and time treatment.

\section{B. Sensory Taste test and Profile Based on Time and Temperature of Fermentation by Ohmic Technology}

Table 2 shows that the best taste attribute taste cuptest results at $35^{\circ} \mathrm{C}$ with an 18 hour fermentation length having a high body value (5.80) while the body value is low (2.17) at $45^{\circ} \mathrm{C}$ with 6 hours fermentation time. 
Table 2. The result of sensory taste test based on temperature and time on fermentation of coffee beans

\begin{tabular}{ccccc}
\hline $\begin{array}{c}\text { Treatment } \\
\text { Temperature }{ }^{\circ} \mathrm{C}\end{array}$ & $\begin{array}{c}\text { Time } \\
\text { (hour) }\end{array}$ & & $\begin{array}{c}\text { Attribute } \\
\text { Sourness }\end{array}$ & Body \\
\cline { 2 - 2 } 35 & 6 & 2.91 & 4.43 \\
& 12 & & 4.57 & 4.59 \\
& 18 & & 4.40 & 5.80 \\
45 & 6 & & 4.84 & 2.17 \\
& 12 & & 3.34 & 2.77 \\
& 18 & & 4.34 & $\underline{5.53}$ \\
\hline
\end{tabular}

Figure 2 shows that at the same temperature treatment in $35^{\circ} \mathrm{C}$ and fermentation time of 6 hours and 18 hours obtained body value (5.80) and bitterness value (4.37).

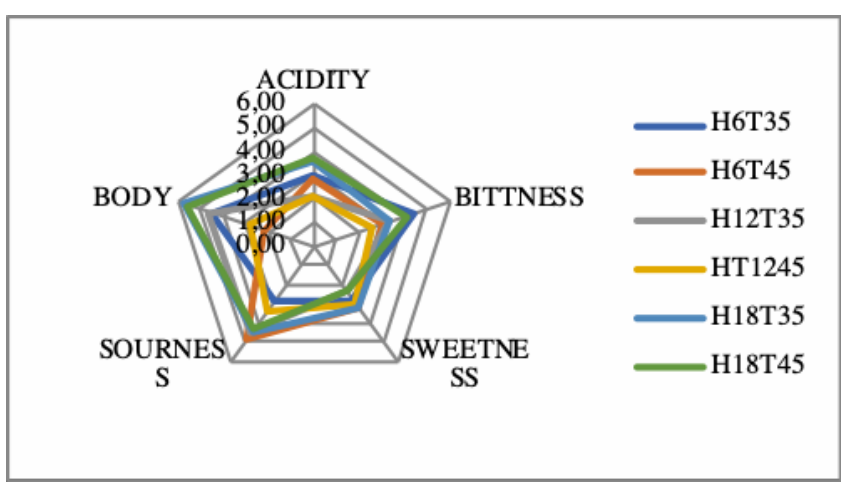

Figure 2. Profile of aroma coffee after fermentation ohmic with temperature and time treatment.

Assessment of coffee characteristics organoleptically include assessment of rice seeds, roasted seeds, and steeping. Assessment of the character of coffee beans of rice and roasted beans has not been able to describe the characteristics of a real coffee so that it is usually only used as a complement to the assessment of the taste of steeping [Lingle., 2013].

In this research, the temperature and the duration of fermentation greatly affect the aroma in coffee. According to [Reta, et al., 2017], which states that the best coffee flavor lasts for 12 hours fermentation with temperature $35^{\circ} \mathrm{C}$ produces the best flavor, flavor, and balance. If the temperature is less than 30
- $\mathrm{C}$ the growth of acid-producing microorganisms will be slow so that it may damage the product. An improper fermentation process will produce coffee beans with low flavor. This is also an advantage of the flavor generated in ohmic fermentation with temperature and controlled fermentation time so that the heat generated by ohmic will spread well on all surfaces of the material to be fermented, compared to the fermentation occurring in the mongoose. The process of fermentation can spur the occurrence of chemical processes that are very useful in the formation of the precursor flavor of coffee beans, namely organic acids, amino acids, and reducing sugars [Lin., 2010].

Low levels of caffeine involves low body values as well. According to [Yusianto., et al., 2013], which states that the body is the consistency of steeping coffee as an internal character that can be assessed because there is a strong impression on the roof of the mouth. Caffeine contributes to body steeping coffee. This can be aligned with the decreased levels of caffeine powder coffee will affect the lower body value. The sensation of texture and taste richness shows the body value of coffee. Thus the longer the fermentation time will result in the final steeper coffee getting bitter. According to Reta et al [Reta., at al., 2017], which states that bittness is a bitter taste that will be the hallmark of coffee. At low levels, the bitter taste helps reduce the acidity of the coffee and adds a dimension to the taste of the drink. But at a high level, the compound that raises the bitter taste of coffee can beat the other flavor components.

\section{IV.CONCLUSION}

Based on the research that has identified the quality of physical, chemical and organoleptic tests Arabica coffee beans, it can be concluded that in order to get quality Arabica coffee beans should be performed for postharvest processing technologies, especially in 
the fermentation process the beans after processing And from the results of this identification will also be used as a comparison to design a fermentation technology Arabica coffee beans, which is an ohmic -based fermentation technology.

\section{ACKNOWLEDGMENTS}

This work is funded by Higher Education Directorate, Ministerial of Research and technology Indonesia through Terapan Research grant program 2019.

\section{REFERENCES}

[1]. Ciptadi W. \& Nasution M.Z. (1985). Pengolahan Kopi. Bogor: Agro Industri Press.

[2]. Dirjen Perkebunan. (2016). Statistik Perkebunan Indonesia Kopi 2015-2017. Jakarta

[3]. Food and agriculture organization of United Nation (FAO). (2016). http://faostat.fao.org terhubung berkala.

[4]. (ICO) Internasional Coffee Organization. 2012. All Exporting Countries Total Production Crop years, England: Internasional Coffee organization.

[5]. International Coffee Organization (ICO). 2015. ICO Annual Review 2013-2014.International Coffee Organization. London.

[6]. Lin C.C. (2010). Approch of Improving Coffee Industry in Taiwan Promote quality of Coffee bean by fermentation. The journal of Internasional management Studies5(1) ; 154- 159.

[7]. Lingle T.R. (2011). The Coffee Cupper's Handbook: Asystematic Guide to the Sensory Evaluation Of Coffee's

[8]. Oktadina F.D., Argo B.D., \& Hermanto M.B. (2013). Pemanfaatan Nanas (Annanas Comosus L. Merr) untuk Penurunan Kadar Kafein dan Perbaikan Cita Rasa Kopi (Coffea sp) dalam Pembuatan Kopi Bubuk. Jurnal Keteknikan Pertanian Tropis dan Biosistem. Vol. 1, No. 3.
[9]. Rahardjo, Pudji. 2012. Panduan Budidaya dan Pengolahan Kopi Arabikadan Robusta. Penebar Swadaya. Jakarta.

[10]. Reta, Mursalim, Muhidong J., \& Salengke. (2017). Characteristic Flavour of Robusta Coffee from South Sulawesi after Fermentation by Ohmic Technology. International Journal of Current Research in biosciences and plant biology. Vol 4 Number 7.

[11]. Ruan, R, Ye, P, Chen and Doona, C.J, 2001, Thermal Tecnologies in Food Processing, CRC Press, New York.

[12]. Salengke S. (2002). Electrothermal Effects of Ohmic Heating on Biomaterials. Ph.D. Dissertation, The Ohio State University, Columbus, $\mathrm{OH}$.

[13]. Soekarto S.T. \& Hubeis M. (1993). Metodologi Penelitian Organoleptik. Program Studi Ilmu Pengan, IPB, Bogor.

[14]. Yusianto, Hulupi R., Sulistyowati, Mawardi S., \& Ismayadi C. (2013). Pengolahan dan komposisi kimia biji kopi dan pengaruhnya terhadap citarasa seduhan. Warta Pusat penelitian Kopi dan Kakao, 15.190-202.

[15]. Yusianto and Sukrisno Widyatomo, 2013. Quality and Flavor Profiles of Arabika Coffee Processed by Some Fermentation Treatments; Temperature,Containers, and Fermentation Agents Addition. Pelita Perkebunan 29(3) 2012, 220-239.

\section{Cite this article as :}

Reta, Henny Poerwanty AS, Salengke, Syamsia, Arnida $\mathrm{M}$, "The Fermentation of Parchment Ohmic Technology Used to Process Coffee Beans (A Wet Black Coffee) Aroma", International Journal of Scientific Research in Science and Technology (IJSRST), Online ISSN : 2395602X, Print ISSN : 2395-6011, Volume 6 Issue 5, pp. 323-327, September-October 2019. Available at doi : https://doi.org/10.32628/IJSRST19663 Journal URL : http://ijsrst.com/IJSRST19663 